Hanisch, Ernst. Der große Illusionist. Otto Bauer (I88I-I938). Böhlau Verlag, Wien [etc.] 201 I. 478 pp. Ill. $€$ 39.00. doi:10.1017/S00208590I3000047

Following the publication of a nine-volume edition of his work (1975-1980) and a highly selective revival of his political rhetoric in the service of "Eurocommunist" ideas in the I 970 s and early I980s, interest in the Austro-Marxist theorist and Social Democratic Party leader Otto Bauer once again faltered. A few more recent projects that seek a connection with Bauer and Austro-Marxism have again emphasized him as the type of a revolutionary intellectual whose universal critique of bourgeois society has helped to perpetuate the idea of a proletarian subject of history - if only in the sense of that Marxian "spectre", as Jacques Derrida called the persistence of the problem of legitimacy for a capitalism unwilling to acknowledge any "society" but only competing individuals.

Other undertakings, in the spirit of the history of ideas, have attempted to rescue certain of Bauer's conceptions, in particular the relative autonomy that Bauer afforded to culture, for a prehistory of "cultural studies". And one of Bauer's early works - Social-Democracy and the Nationalities Question (1907) - maintains a persistent and monumental presence when the history of the Habsburg monarchy is discussed as a virtual model for an efficient multi-ethnic imperium and a transnational order of peace today. Now, with Ernst Hanisch's Der grosser Illusionist Otto Baner (I88I-I938), we have the first biography based on intensive archival research and (more or less) the entire published work, a biography whose ambivalent judgements about both Bauer's personality and his work will be unavoidable for any serious future research. On the other hand, this biography, whose author is familiar with neither the history of Marxism nor post-Marxist theory, inevitably raises questions as to the suitability of the methods and critique on which it is founded, based on the author's lack of awareness of the historicity of his subject.

But who was Otto Bauer? Born in Vienna, the son of a Bohemian textile manufacturer of Jewish origin, Bauer joined the socialist student organization, participated in the "Marx-Studien" theory project, and in 1907, aged only twenty-six, became secretary of the group of Social Democratic deputies in the Reichsrat. In the same year he co-founded the theoretical journal Der Kampf, and from I9I 2 was also a member of the editorial board of the party organ, Arbeiter-Zeitung. He continued to play a dominating role in both these activities until the end of the SDAP in 1934, as well as functioning as de facto group leader of the Social Democratic parliamentary fraction and informal party chairman during the First Republic. After his return from Russia, where he had been a prisoner of war, Bauer assumed for a time the role of spokesman for the party's left opposition (which led also to his victory in the contest for the leadership of the Austrian Social Democrats against his competitor Karl Renner who had been compromised by the war), but he turned decisively and successfully against the revolutionary tendencies in the workers' and soldiers' councils. As a short-lived minister, he ran Austrian foreign policy from March to June 1919, and subsequently had a key influence on the refounding of the Labour and Socialist International, standing on its left wing. He died in Paris in 1938 after four years in exile, having moved there from Brno following Hitler's takeover of Austria.

As this biography shows without question, Otto Bauer was the leading political personality of the First Republic and enjoyed international prominence beyond the circle of the two internationals. Yet documents on Bauer's life are rare - even material about his day-to-day work. What is available had previously not been made use of, or ignored as 
it contradicted the established legends of official party history. Ernst Hanisch's book makes important corrections to this in certain chapters. For example, the account of Bauer's term as Foreign Minister shows him not simply as a convinced advocate of "Anschluss" with Germany, but also - based on his confidential letters to Karl Kautsky and a violently polemical correspondence with his Berlin delegate and trusted agent, Ludo Moritz Hartmann - as a nervous political pragmatist who failed in a diplomatic intrigue, i.e. the attempt to conclude secret economic agreements with Germany designed to create a fait accompli for the peace negotiations in Saint-Germain and trick the Entente.

I mention this here, as Bauer's subsequent arguments based on extensive historical and theoretical assumptions, designed to explain his opposition to a central European Soviet Revolution in "materialist" terms, have become symptomatic of "Austro-Marxism"; also because a textual exegesis without archival research has sought to use Otto Bauer as an example of a myth of "scientific" politics of Marxist provenance, an attempt that is often repeated. A further chapter that offers a surprising corrective from a strong historiographic perspective is that on the years of Bauer's exile in Czechoslovakia. The reports from the Austrian embassy, which formerly were scarcely considered of any value, give an insight into the steady constriction of the room for political manoeuvre on the part of emigrés in Czechoslovakia due to diplomatic pressure from the Austro-fascist regime, reinforced by the resentment that Bauer encountered on the part of State President, Edvard Benes. The preference of Bauer and his party for an "Anschluss" with Germany had a paradoxical effect here: for example, police restrictions on the Arbeiter-Zeitung illegally produced in Brno. Historiography of resistance and exile between I934 and 1938 will not be unaffected by these aspects.

Hanisch indicates already in the introduction to his book that a classical biographical account is as foreign to his intent as is intervention in the history of theory. Though his discussion of Otto Bauer is in no way arbitrary and indicates in the historiographic field a scarcely comprehensible vacuum (at least as far as central Europe is concerned), over and above the interest of Bauer as an individual it serves for the author as a model test of historical writing today. This means asking first of all whether a hesitant German social history - Hanisch himself prefers the term "structural history" - can make use of recent tendencies in cultural theory. It also means, however, establishing what effect the collapse of "really existing socialism" has on thinking about history. Both arise from the dissatisfaction of the author, repeatedly expressed elsewhere, about the presence of the so-called "postmodern" and its dissolving effect on the validity of foundational categories of historiography. In the one case, coming back to the book presented, this leads to local applications of psycho-history, intellectual history, and gender history to the "structures", in the other case to a paradox: what legitimizes the title of "grand illusionist" is the supposed refutation of the "grand narrative" as to the advent of socialism by the events of I989-1991, simply to be replaced by another grand narrative, that of the triumph of liberal democracy and the free market economy.

In his preface Ernst Hanisch considers the difficulties he confronts in the project of a biography and its mediating work between the particular and the universal, as well as between genealogical and archaeological procedures. He himself opts to identify the universal with an established historical narrative and to anchor the contingencies in this as need requires. By superimposing shapeless political "event history" in the form of consensual caesuras, the conceptual potentials of "structures" are not exhausted and the above mentioned cultural-theory approach is not fully made productive. For example, the 
educational system of the Habsburg monarchy that Otto Bauer experienced is certainly taken into account in the reflection of patriotic books of history and their possible effects on Bauer's historical thought. On the other hand, the key role of rhetoric and ancient languages in the Austrian educational system, which relegated the natural sciences and cultivated a particular disposition to theatrical political communication, goes quite unmentioned - although Hanisch time and again takes issue with the "male-soldierly" speech of Bauer as politician, which he presents as both an individual property and a fatal gesture of threat.

The same applies to the way that he deals with the historical sociology of the intellectuals, making strategic use of texts to indicate - in Hanischs' view - Bauer's fatal path to becoming one of the politico-intellectuals. We meet these intellectuals only in the context of fin-de-siècle research and the academic field, not in relation to the new radical intellectuals of the postwar period, who (coming from the media and from the applied sciences) became the left opposition to Bauer in the party. Not to speak of the "organic intellectuals" who formed the illegal party.

The application of psycho-history is also less than successful. True, the fact that Bauer's sister Ida and his family became one of the most prominent of Sigmund Freud's "case studies" already suggests reference to two previous studies that link Bauer's political attentism to his need to balance family conflicts. The striking rhetorical question as to whether Bauer's drawing up of programmes to stimulate industrial growth was perhaps "an unconscious reflex of an industrialist's son" (p. 272) is, however, more than just playful. It leads to a fundamental problem of method in Hanisch's discussion of Bauer as "illusionist".

This revelation is based on an axiom that was very likely the one element Bauer shared with everyone who confessed to socialism before the social democratic turn to the corporatist welfare state after 1945: the axiom that a socialist society would be based on the socialization of the means of production. What is incomprehensible in Hanisch's assertion is not so much his denunciation of this axiom as such, but rather that as a historian he dissimulates its contemporary meanings and actualizations in their changing contexts. Silence about the transformation of the economy by the wartime economic trusts, the omission of any information about the "bourgeois" planning debates promoted by Rathenau, ignoring the "democratic" planned-economy concepts of industrialists such as Hermann Broch on the basis of the council system, the significant non-mention of Otto Neurath, the Austrian theorist of economic planning and representative par excellence of a "social engineering" - all this is not only neglect, but actually deliberate. It serves to present Marxism as a single unified body of ideas, out of touch with everyday life. If the Vienna marginal utility school of economics with its supposedly universal validity is considered the only relevant discursive context of Bauer's theory of society, the verdict on this "illusionist" is already cast. The rest is decoration. In his summing up, Ernst Hanisch himself appears to be dissatisfied with the generalized results that emerge from such an approach. This book of 400 pages ends up more as a staging post that could serve as an obituary for a statesman.

\section{Siegfried Mattl}

Ludwig Boltzmann Institut für Geschichte und Gesellschaft, Hofburg, Zuckerbäckerstiege 17, A-ıого Vienna, Austria

E-mail: siegfried.mattl@geschichte.lbg.ac.at 